\title{
PERSEPSI MASYARAKAT TERHADAP PEMBULATAN HARGA \\ PADA TRANSAKSI JUAL BELI MENURUT SYARI'AT ISLAM DI MINIMARKET INDOMARET KELURAHAN PONTAP KOTA PALOPO
}

\author{
Ilham $^{1}$, Ilasari ${ }^{2}$ \\ ilham@gmail.com
}

\begin{abstract}
The main problems in this thesis are (1) Public perception of rounding off prices in buying and selling transactions at Indomaret minimarkets; (2) the Islamic view of replacing the remaining money purchased with candy at the Indomaret minimarket.

In this study, the authors used this type of field research, the design used was qualitative research, namely research produced data in the form of written or spoken words from people who could be observed. This research raises the facts. There are two sources of data that researchers use, namely primary data sources and secondary data sources. The primary data source is data that is directly taken from the research object, namely Indomaret cashiers and customers. The primary data source comes from field data obtained from observations and interviews. The secondary data source is data taken in the form of Indomaret documents. The results of the study show that most people accept price rounding on the grounds that they are used to it, but there are still a small proportion of people who are dissatisfied and do not agree with rounding prices. If there is a buyer who feels less willing to fulfill the remaining money, he can choose to stick to what the seller said or cancel the sale and purchase. As for the Islamic view of replacing the remaining money returned with candy, it is permissible to see the scarcity of change, which makes Indomaret managers provide candy instead. This raises the law of one rule which reads "any difficulty creates convenience". The abilities and potentials of humans in carrying the law vary, so there needs to be a way to avoid difficulties by providing legal exceptions.
\end{abstract}

Keywords: Public Perception, Price Rounding, Islamic Syari'at, Indomaret Minimarket.

\begin{abstract}
ABSTRAK
Permasalahan pokok dalam skripsi ini adalah (1) Persepsi masyarakat terhadap pembulatan harga pada transaksi jual beli di minimarket Indomaret; (2) pandangan Islam tentang penggantian uang sisa pembelian dengan permen di minimarket Indomaret.
\end{abstract}


Dalam penelitian ini penulis menggunakan jenis penelitian lapangan, desain yang digunakan adalah penelitian kualitatif yaitu penelitian menghasilkan data berupa kata-kata tertulis atau lisan dari orang-orang yang dapat diamati. Penelitian ini mengangkat fakta. Sumber data yang peneliti gunakan ada dua yaitu sumber data primer dan sumber data sekunder. Sumber data primer yaitu data yang langsung diambil dari objek peneliti yaitu kasir Indomaret dan pelanggan. Sumber data primer ini berasal dari data lapangan diperoleh dari hasil observasi dan wawancara. Sumber data sekunder yaitu data yang diambil berupa dokumen Indomaret.Hasil penelitian menunjukkan bahwa sebagian besar masyarakat menerima adanya pembulatan harga dengan alasan sudah terbiasa tetapi masih ada sebagian kecil masyarakat yang merasa kurang puas dan tidak setuju jika praktek pembulatan harga yang dilakukan. Bila dalam penggenapan uang sisa pembelian ini ada pembeli yang merasa kurang rela, ia dapat memilih untuk tetap mengikuti apa yang dikatakan penjual atau membatalkan jual beli tersebut. Adapun pandangan Islam tentang penggantian uang sisa pengembalian dengan permen yaitu dibolehkan melihat kelangkaan uang receh sehingga membuat pengelola Indomaret menyediakan permen sebagai gantinya. Hal ini memunculkan hukum satu kaidah yang berbunyi "adanya kesulitan memunculkan adanya kemudahan“. Kemampuan dan potensi yang dimiliki manusia dalam memikul hukum itu berbeda-beda, sehingga perlu diadakan jalan untuk menghindarai kesukaran dengan mengadakan pengecualian hukum.

Kata Kunci : Persepsi Masyarakat, Pembulatan Harga, Syari'at Islam, Minimarket Indomaret.

\section{PENDAHULUAN}

A. Latar belakang

Perkembangan pasar modern di Indonesia kini semakin marak. Kehadiran pasar modern telah memberi warna tersendiri bagi perkembangan perekonomian. Dalam jangka waktu yang singkat beberapa pelaku usaha pasar modern dengan kemampuan kapital yang luar biasa melakukan aktivitasnya di Indonesia.

Kehadiran para pelaku ini, bagi konsumen di Indonesia di satu sisi memang sangat menggembirakan. Konsumen dimanjakan dengan berbagai hal positif terkait dengan kenyamanan saat berbelanja, keamanan, kemudahan, variasi produk yang semakin beragam, kualitas produk yang terus meningkat karena hadirnya persaingan. Pesatnya perkembangan 
perekonomian saat ini diikuti juga berkembangnya berbagai tempat perbelanjaan modern di berbagai kota besar di Indonesia, begitu juga di Palopo. Salah satu tempat perbelanjaan yang terletak di Palopo yaitu minimarket indomaret.

Kaum muslim di tuntut untuk bertindak secara Islami dalam bisnis mereka karena Allah swt, akan menjadikan saksi dalam setiap transaksi yang mereka lakukan seperti jujur dan berkata benar. Karena kejujuran dan kebiasaan berkata adalah kualitas-kualitas yang harus dikembangkan da dipraktekkan oleh para pengusaha Muslim. Oleh sebab itu kejujuran dan kebenaran sangat penting bagi seorang pengusaha Muslim karena adanya kebutuhan untuk mendapatkan keuntungan dan godaan untuk memperbesar kemampuan produk atau jasa mereka selama puncak penjualan. ${ }^{1}$

Islam memandang aktivitas ekonomi secara positif. Semakin banyak manusia yang terlibat dalam aktivitas ekonomi maka akan semakin baik, sepanjang tujuan dari prosesnya sesuai dengan ajaran Islam. Ketakwaan kepada Tuhan tidak berimplikasi pada penurunan produktivitas ekonomi, sebaliknya justru membawa seseorang untuk lebih produktif. Kekayaan dapat mendekatkan kepada Tuhan selama dilakukan dengan cara-cara yang sesuai dengan nilai-nilai Islam.

Seiring dengan perkembangan zaman yang semakin maju dan modern. Kegiatan jual beli pun juga berkembang ke bentuk-bentuk yang lebih modern. Bentuk modern dari bentuk perdagangan yang saat ini banyak dijumpai salah satunya adalah minimarket indomaret.

Zaman yang maju menjadikan manusia selalu ingin mencari sesuatu yang lebih mudah dan praktis, sehingga tidak salah jika keberadaan minimarket Indomaret dapat diterima oleh masyarakat dengan baik. Berbagai fasilitas yang ditawarkan membuat masyarakat lebih dimanjakan, sehingga banyak dari masyarakat yang lebih memilih berbelanja di tempat tersebut.

Keberadaan minimarket Indomaret sebagai suatu bentuk yang lebih modern dan baru dari pasar tradisional, ternyata juga memberikan benntuk-bentuk baru terutama dalam bentuk transaksinya (akad). Dalam akadnya terutama saat mengembalikan uang sisa pembelian. Sering kali uang kembalian kita digenapkan atau terkadang diganti dengan permen. Hal yang baru ini terkadang masih menimbulkan tanda tanya di kalangan masyarakat. Hal baru tersebut dianggap berbeda dari transaksi biasa yang dilakukan dipasar tradisional.

\footnotetext{
${ }^{1}$ Rafik Issa Beekun, Etika Bisnis Islam, (Cet. I; Yogyakarta: Pustaka Pelajar, 2004), h. 105
} 
Dengan melihat permasalahan yang ada pada latar belakang di atas, maka sudah jelas bahwa sistem transaksi jual beli di ditinjau dari syariat Islam sangat perlu diperhatikan khusus terutama pada minimarket indomaret di kelurahan Pontap kota Palopo, dan ini merupakan tantangan tersendiri bagi penulis.

\section{KAJIAN PUSTAKA}

Jual beli dibolehkan dengan adanya dalil dari Al-Qur'an, As-Sunnah, dan juga Ijma' ulama. Adapun dari Al-Qur'an adalah firman Allah swt:

a. Surah Al-Baqarah/2: 275

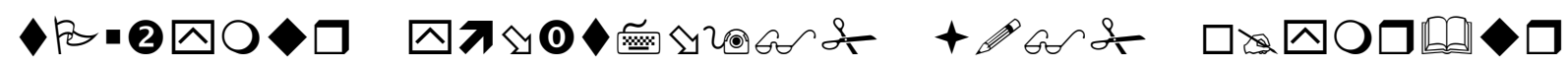 2 क्षं क्ष}

Terjemahnya:

"Dan Allah telah menghalalkan jual beli dan mengharamkan riba"

b. Surah An-Nisa/4 : 29

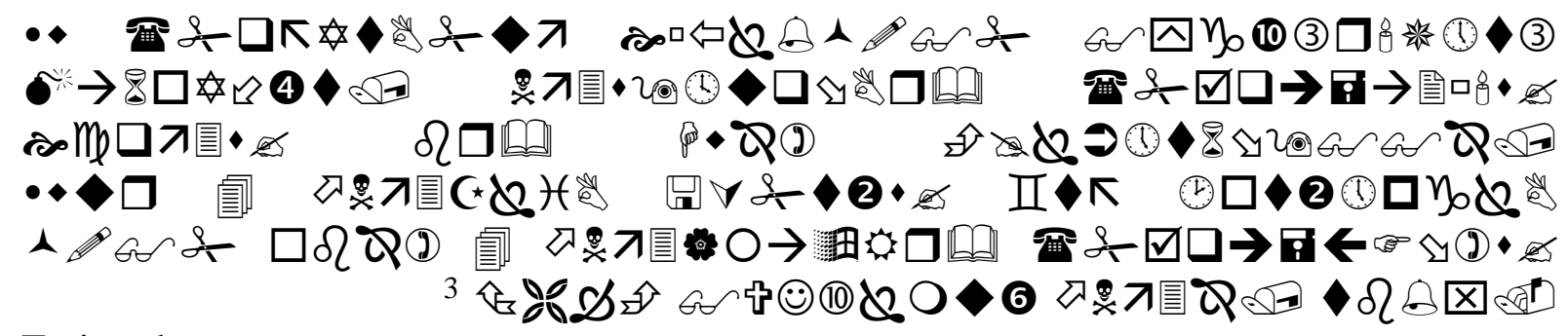

Terjemahnya:

"Hai orang-orang yang beriman, janganlah kamu saling memakan harta sesamamu dengan jalan yang batil, kecuali dengan jalan perdagangan yang berlaku dengan suka sama-suka di antara kamu. dan janganlah kamu membunuh dirimu. Sesungguhnya Allah adalah Maha Penyayang kepadamu".

Dasar hukum berdasarkan sunnah Rasulullah saw, antara lain yaitu :

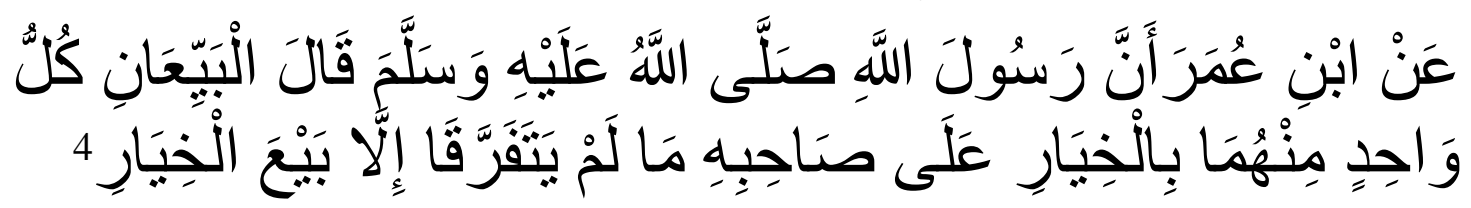

47

${ }^{2}$ Departemen Agama RI, Al-Qur'an dan Terjemahnya, (Edisi Revisi; Bandung: Diponegoro, 2011)., h.

${ }^{3}$ Ibid., h. 83

${ }^{4}$ Muslim Imam Abu Husain bin Hajjaj Al Qusyari Annaisaburi, Shahih Muslim Juz 2, (Lebanon: Dar Al Fikr-Bairut, 1993)., h.10

Journal Of Institution And Sharia Finance : Volume 3 Nomor 1 Juni 2020 
"Dari Ibnu Umar bahwasannya Rasulullah saw bersabda: "Dua orang yang bertransaksi, maka masing-masing dari keduanya boleh memilih atas partnernya selama keduanya belum berpisah, kecuali jual beli khiyar, yaitu ditentukannya pilihan dari awal transaksi." (Shahih Muslim No. 2821)"

Ijma' ulama telah sepakat bahwa jual beli diperbolehkan dengan alasan bahwa manusia tidak akan mampu mencukupi kebutuhan dirinya tanpa bantuan orang lain. Namun demikian, bantuan atau barang milik orang lain yang dibutuhkan itu, harus diganti dengan barang lainnya yang sesuai. ${ }^{5}$

\section{Rukun dan Syarat Jual Beli}

Di dalam fiqh muamalat, khususnya pada pembahasan jual beli, terdapat empat konsep yang berhubungan dengan keuntungan yang diterima penjual. Keempat konsep ini dikategorikan sebagai ragam jual beli berdasarkan harga, yaitu; pertama al-wadhia yaitu penjual menjual barang kepada pembeli dengan harga yang lebih murah dari harga pembelian; kedua attauliyat, yaitu penjual menjual barang kepada pembeli dengan harga yang sama dengan harga pembelian; ketiga al-musawamat yaitu penjual yang harga jualnya menurut kesepakatan antara penjual dan pembeli tanpa melihat harga pokok pembelian dan keempat al-murabahat saling menjual suatu barang dengan menegaskan harga belinya kepada pembeli dan pembelinya membayar dengan harga yang lebih sebagai laba. ${ }^{6}$

Rukun jual beli ada tiga, yaitu akad (ijab kabul), orang-orang yang berakad (penjual dan pembeli), dan ma'kud alaih (objek akad).

Akad ialah ikatan kata antara penjual dan pembeli. Jual beli belum dikatakan sah sebelum ijab dan kabul dilakukan sebab ijab kabul menunjukkan kerelaan (keridhaan). ${ }^{7}$ Pada dasarnya ijab kabul dilakukan dengan lisan, tetapi kalau tidak mungkin, misalnya bisu atau yang lainnya, boleh ijab kabul dengan surat-menyurat yang mengandung arti ijab dan kabul.

Adanya kerelaan tidak dapat dilihat sebab kerelaan berhubungan dengan hati, kerelaan dapat diketahui melalui tanda-tanda lahirnya, tanda yang jelas menunjukkan kerelaan adalah ijab dan kabul.

\footnotetext{
${ }^{5}$ Rahmat Syafe'i, Fiqih Muamalah, (Cet. I; Bandung: Pustaka Setia)., h. 74

${ }^{6}$ Atang Abd Hakim, Fiqih Perbankan Syari'ah, (Bandung; Refika Aditama, 2011)., h. 225

${ }^{7}$ Hendi Suhendi, Fiqh Muamalah, (Jakarta: Raja Grafindo Persada, 2002)., h. 70
} 
Jual beli yang menjadi kebiasaan, misalnya jual beli sesuatu yang menjadi kebutuhan seharihari tidak disyaratkan ijab dan kabul, ini adalah pendapat jumhur. Menurut fatwa Ulama Syafi'iyah, jual beli barang-barang yang kecil pun harus ijab dan kabul, tetapi menurut Imam Al-Nawawi dan Ulama Muta'akhirin Syafi'iyah berpendirian bahwa boleh jual beli barangbarang yang kecil dengan tidak ijab dan kabul seperti membeli sebungkus rokok. ${ }^{8}$

Agar jual beli sah, harus memenuhi syarat-syaratnya. Diantaranya ialah syarat yang berkaitan dengan barang yang dijual belikan dengan harga tertentu. ${ }^{9}$ Syarat-syarat jual beli adalah sebagai berikut:

a. Syarat yang berkaitan dengan pihak-pihak pelaku; mereka harus memiliki kompetensi dalam melakukan aktifitas itu, yakni sudah akil baligh serta berkemampuan memilih. Maka tidak sah jual beli yang dilakukan anak kecil yang belum nalar, orang gila atau orang yang dipaksa.

b. Syarat yang berkaitan dengan obyek jual beli; obyek jual beli harus suci, bermanfaat, biasa diserah terimakan dan merupakan milik penuh penjual. Maka tidak sah memperjual belikan bangkai, darah daging babi dan barang lain yang menurut syara' tidak ada manfaatnya. Juga tidak syah memperjual belikan barang yang masih belum berada dalam kekuasaan penjual, barang yang tidak mampu diserahkan dan barang yang berada ditangan seseorang yang tidak memilikinya.

c. Syarat yang berkaitan dengan shighat akad, yaitu ijab dan Kabul dilakukan dengan satu majelis, artinya antar penjual dan pembeli hadir didalam satu ruangan yang sama, kabul sesuai dengan ijab, contoh aku jual baju ini 10 ribu, pembeli menjawab saya beli baju ini 10 ribu.

Maksud dari satu ruangan adalah bukan dalam artian satu ruangan khusus, menurut ulama kontemporer Mustafa Ahmad Az-Zarqa' dan Wahbah Zuhaily berpendapat bahwa satu majelis tidak harus diartikan hadir dalam satu tempat, tetapi satu situasi dan kondisi, meskipun antara keduanya berjauhan tetapi membicarakan obyek yang sama.

Tentang persyaratan terjadinya ijab dan qabul dengan lisan jumhur ulama berpendapat tanpa harus mengucapkan ijab dan qabul ulama sepakat kalau hal itu diperbolehkan apabila hal tersebut sudah menjadi suatu kebiasaan disebuah negeri. ${ }^{10}$

\footnotetext{
${ }^{8}$ Ibid

${ }^{9}$ Ibrahim Muhammad Al-Jamal, Fiqih Muslimah Ibadat Mu'amalat, (Cet. III; Jakarta: Pustaka Amani, 1999)., h. 365

10 Ibid.
}

Journal Of Institution And Sharia Finance : Volume 3 Nomor 1 Juni 2020 
Adapun syarat mengadakan akad yaitu:

a. Syarat orang yang berakad:

1) Orang yang berakad harus berakal, bisa membedakan mana yang benar dan mana yang salah.

2) Orang yang berakad harus banyak berperan

b. Barang yang diakadkan harus memenuhi syarat:

1) Barangnya harus ada

2) Barangnya berupa harta yang jelas harganya

3) Barangnya dimiliki sendiri, artinya terjaga

4) Barang itu dapat diserahkan sewaktu akad

Secara umum syarat sah jual beli yaitu segala sesuatu yang harus ada pada setiap macam jual beli, sehingga dianggap sah secara syara'. Agar dianggap sah akad jual beli harus terhindar dari enam aib, yaitu: ketidakjelasan tentang keadaan barang (karena bisa menimbulkan perselisihan), adanya pemaksaan, pemberian batas waktu, adanya penipuan, adanya bahaya dan syarat-syarat yang merusak.

Secara khusus syarat sah jual beli yaitu syarat yang khusus pada sebagian jual beli dan bukan bagian jual beli yang lain. Syarat-syarat yang khusus untuk beberapa jenis jual beli adalah sebagai berikut: ${ }^{11}$

a. Menahan barang pada transaksi jual beli barang yang mudah dipindahkan. Bila seseorang menjual barang yang mudah dipindah dan dulu pernah dia beli, kemudian untuk sahnya jual beli disyaratkan hendaknya barang itu ditahan olehnya dari penjual yang pertama, karena barang yang dipindah banyak rusaknya. Maka pada jual beli yang kedua sebelum ia menahan barang dimaksud terdapat unsur penipuan. Tetapi bila barang yang dijual berupa tanah atau rumah, maka jual belinya boleh dilakukan sebelum barang tersebut ditahan, menurut pendapat Abu Hanifah dan Abu Yusuf.

b. Mengetahui harga pertama bila jual belinya berbentuk murabahah, tawliyah, wadli'ah, atau syarikah.

c. Saling menahan dua barang pengganti sebelum berpisah bila jual beli bentuk sharf (pertukaran mata uang)

d. Adanya persesuaian pada dua barang pengganti bila barangnya bersifat riba dan terhindar dari subhat riba

\footnotetext{
${ }^{11} \mathrm{Ibid}$
} 
e. Terpenuhi syarat salam pada jual beli berbentuk salam

Menahan hutang-hutang yang tetap dalam tanggungan, seperti barang salam, modal salam, jual beli barang dengan hutang atas tanggungan orang selain pembeli, maka jual beli ini tidak sah dari orang lain yang bukan menanggung hutang kecuali setelah ditahan. Sebagaiman tidak sah orang yang punya salam (pembeli) untuk menjual barang salam sebelum dia menahan barang dari penjual. Dan juga tidak sah bagi orang yang menghutangi, membeli barang dengan dengan uang hutangnya dari orang selain orang yang berhutang sebelum barang itu ditahan. $^{12}$

Jika dalam syarat sah tidak lengkap, maka akad akan menjadi fasid. Jika dalam salah satu syarat nafadz tidak dipenuhi, maka akad menjadi mauquf. Dan jika salah satu syarat luzum tidak dipenuhi, maka pihak yang bertransaksi memiliki hak khiyar, meneruskan atau membatalkan akad.

Dijelaskan bahwa dalam setiap transaksi ada beberapa prinsip dasar (asas-asas) yang diterapkan syara', yaitu :

1. Setiap trasaksi pada dasarnya mengikat orang (pihak) yang melakukan transaksi, kecuali apabila transaksi itu menyimpang dari hukum syara', misalnya memperdagangkan barang haram, sebagaimana firman Allah swt dalam Al-Qur'an surah Al-Maidah/5 : 1

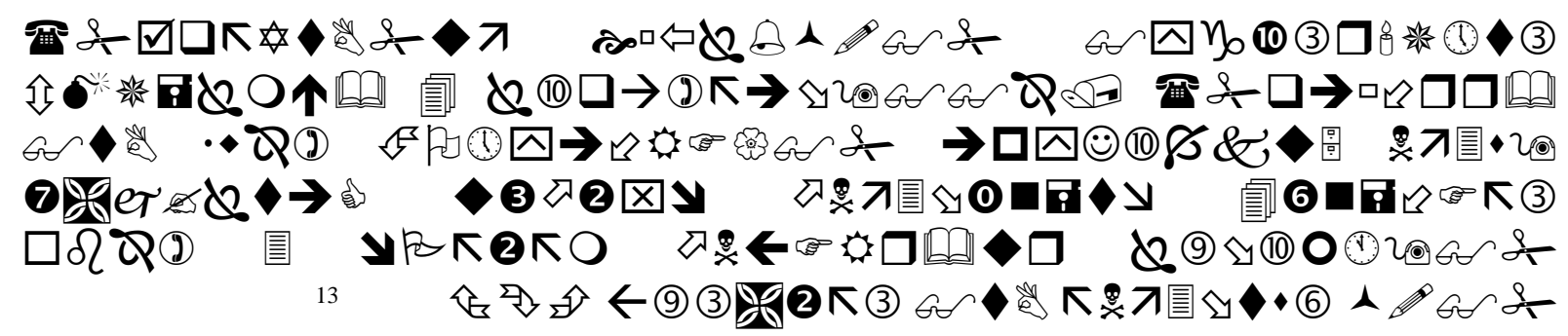

Terjemahnya :

"Hai orang-orang yang beriman, penuhilah aqad-aqad itu. Dihalalkan bagimu binatang ternak, kecuali yang akan dibacakan kepadamu. (yang demikian itu) dengan tidak menghalalkan berburu ketika kamu sedang mengerjakan haji. Sesungguhnya Allah menetapkan hukumhukum menurut yang dikehendaki-Nya."

2. Syarat-syarat transaksi di rancang dan dilaksanakan secara bebas tetapi penuh tanggung jawab, tidak menyimpang dari hukum syara' da adab sopan santun.

\footnotetext{
${ }^{12}$ Wiroso, Jual Beli Murabahah, (Yogyakarta: Logung Pustaka, 2009)., h. 20

${ }^{13}$ Departemen Agama RI, Al-Qur'an dan Terjemahnya, op. cit., h. 106
} 
3. Setiap transaksi dilakukan secara sukarela, tanpa ada paksaan dari pihak manapun, sebagaimana dalam Al-Qu'an surah An-Nisa/4 : 29

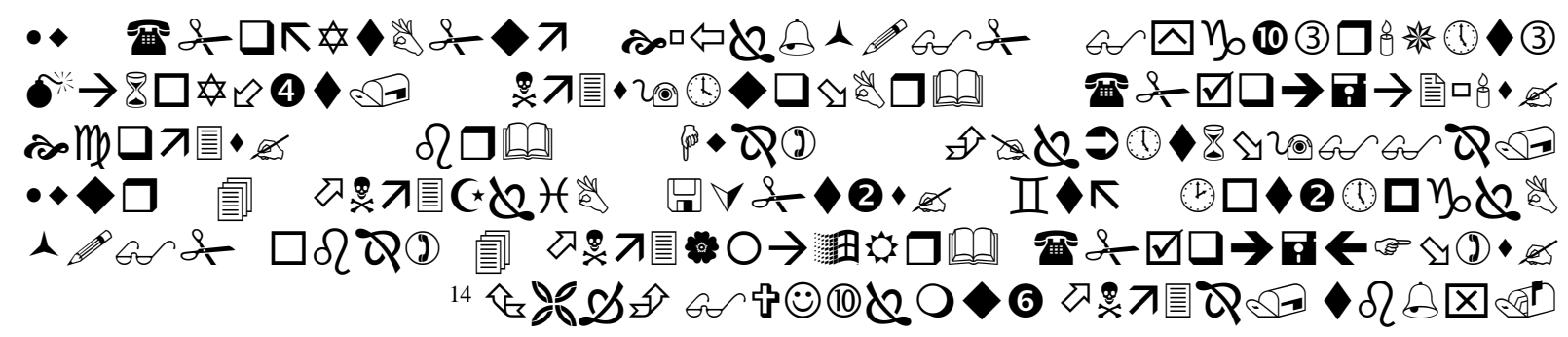

Terjemahnya :

"Hai orang-orang yang beriman, janganlah kamu saling memakan harta sesamamu dengan jalan yang batil, kecuali dengan jalan perniagaan yang Berlaku dengan suka sama-suka di antara kamu. Dan janganlah kamu membunuh dirimu sesungguhnya Allah adalah Maha Penyayang kepadamu."

4. Islam mewajibkan agar setiap transaksi, dilandasi dengan niat yang baik dan ikhlas karena Allah swt. Sehingga terhindar dari segala bentuk penipuan.

5. Adat kebiasaan yang tidak menyimpang dari syara' boleh digunakan untuk menentukan batasan atau kriteria-kiteria dalam transaksi. Misalnya dalam sewa-menyewa rumah. $^{15}$

Jika asas-asas transaksi ekonomi dalam Islam dilaksanakan, maka tujuan filosofis yang luhur dari sebuah tansaksi, yakni memperoleh mardatillah (keridhaan Allah swt) akan terwujud.

\section{HASIL DAN PEMBAHASAN PENELITIAN}

Persepsi Masyarakat Terhadap Pembulatan Harga Pada Transaksi Jual Beli di Minimarket Indomaret Kelurahan Pontap

Masyarakat saat ini memang lebih banyak memilih untuk berbelanja di minimarket yang kini telah banyak dijumpai diberbagai tempat.Mereka merasa lebih dekat, lebih nyaman dan lebih praktis.Tidak perlu susah-susah menawar dan tidak harus merasakan pengapnya udara pasar.Selain itu, di Indomaret juga ada kegiatan promosi seperti memberikan harga khusus, undian berhadiah maupun hadiah langsung.

Menurut Linda, masyarakat kelurahan Pontap dalam wawancara mengatakan bahwa :

\footnotetext{
${ }^{14}$ Ibid, h. 83

${ }^{15}$ Muhammad Nur Ichwan Muslim, loc. cit
} 
"Suka belanja di Indomaret karena dekat dengan rumah tidak perlu jauh-jauh untuk pergi ke pasar ketika ingin membeli kebutuhan makanan. Selain itu di Indomaret juga sering ada discountsehingga bisa membeli barang yang kita inginkan dengan harga yang lebih murah. ${ }^{16}$ "

Adapun Nasna yang juga salah satu masyarakat kelurahan Pontap tepatnya tinggal di jalan Lingkarmengatakan :

"Pada saat belanja di Indomaret total belanjaan saya sekitar Rp. 50.000,- tak di sangka saya langsung diberikan hadiah minuman botol, disitu saya heran dan kasir menjelaskan bahwa saya diberikan hadiah karena belanjaan saya lebih dari Rp. 50.000,-. Saya senang dengan hadiah yang di berikan Indomaret. ${ }^{17}$,

Saat ini penyediaan uang receh memang menjadi suatu masalah yang klasik bagi para pedagang.Hal ini memaksa pedagang ritel khususnya pengelola minimarket Indomaret melakukan praktek pengenapan uang sisa pembelian.Dan praktek pengenapan seperti ini telah banyak dijumpai di berbagai pasar swalayan, supermarket dan minimarket lainnya. Seperti yangdikatakan Rahmiati selaku kasir Indomaret kelurahan Pontap dalam wawancarabahwa :

Di Indomaret, pada saat poses pembayaran, kasir akan menggenapkan uang sisa pembelian yang mempunyai nominal Rp.50,- Rp.100,- misalnya menunjukkan Rp.1.950,- maka kasir akan meminta pembeli untuk membayar Rp.2.000,- seperti yang kita ketahui saat ini sangat sulit mendapatkan uang pecahan kecil atau uang receh. Untuk itu kasir Indomaret akan meminta izin kepada pembeli apakah uang sisa kembalian tersebut mau di gantikan dengan permen atau ikhlas di sumbangkan. Jika pembeli ingin di gantikan dengan permen maka kasir akan memberikan permen. Jika pembeli ikhlas menyumbangkan maka hasil pembulatan tersebut di kumpulkan dan akan di sumbangkan kepada anak-anak kurang mampu. ${ }^{18}$

Ketika penulis melakukan penelitian di Indomaret kelurahan Pontap, penulis juga melakukan wawancara dengan beberapa konsumen diantaranya yaitu :

a. Sukma, masyarakat jalan Yos Sudarso dalam wawancara bahwa saat belanja di Indomaret uang sisa kembalian masih ada Rp. 200,- tapi kebetulan tidak ada uang receh

\footnotetext{
${ }^{16}$ Linda, masyarakat kelurahan Pontap, wawancara, (tanggal 11 Mei 2016)

${ }^{17}$ Nasna, masyarakat, wawancara, (tanggal 11 Mei 2016)

${ }^{18}$ Rahmiati, kasir Indomaret kelurahan Pontap, wawancara (tanggal 10 Mei 2016)
} 
dan kasir mengatakan kembaliannya bisa di sumbangkan, katanya sumbangan ini untuk anak-anak kurang mampu jadi di ikhlaskan. ${ }^{19}$

b. Mita, masyarakat yang tinggal di jalan Lingkar juga pernah mengalami pembulatan harga di Indomaret Pontap. Mita membeli sabun mandi cair seharga Rp.18.400,- dibulatkan menjadi Rp.18.500,- hasil kembalian di bulatkan dan digantikan dengan permen,ini terjadinya dikarenakan habisnya uang receh yang telah disediakan oleh kasir. Dalam hal ini Mita menerima permen yang diberikan oleh kasir dengan alasan sisa kembalian adalah Rp.100,- dan itu setara dengan permen tersebut. ${ }^{20}$

c. Iksan, masyarakat yang juga tinggal di jalan Lingkar, saat belanja di Indomaret ia membayar total belanjanya Rp.40.450,- dengan Rp.50.000,- dan kemudian ia hanya menerima uang kembalian sebesar Rp.9.500,- meski seharusnya yang diterima adalah Rp.9.550,-. Meskipun pada awalnya sempat merasa bingung, tetapi ia menganggap semua itu tidak apa-apa mengingat hal semacam ini tidak hanya terjadi di Indomaret tetapi juga terjadi di supermarket atau minimarket lainnya.

d. Isma, masyarakat yang tinggal di Jalan Tappong membeli sulight seharga Rp.13.300., Isma membayar menggunakan uang Rp. 20.000,- dengan kembalian Rp. 6.500,- ditambah permen sebanyak 2 biji, padahal seharusnya kembalian Rp. 6.700,- Isma ingin uangnya dikembalikan bukan diganti dengan permen. Saat ditanyakan kasir mengatakan tidak ada uang kecil, kalau mau dibayar dengan uang pas Rp.13.300,- dan kebetulan Isma juga tidak membawa uang receh sehingga untuk memperlancar transaksi agar tidak berlama-lama maka Mita menerima permen tersebut. $^{21}$

e. Risma, masyarakat tinggal di jalan Carede, merasa kurang puas jika uang kembaliaanya digenapkan. Dia akan merasa lebih puas jika uang kembaliannya dikembalikan secara utuh tanpa adanya penggenapan. ${ }^{22}$

Dari hasil wawancara, penulis melihat praktek penggenapan uang sisa pengembalian sudah menjadi kebiasaan masyarakat tidak hanya di Indomaret tetapi juga terjadi di toko-toko, minimarket dan supermarket yang lain. Meskipun mayoritas masyarakat telah menganggap

\footnotetext{
${ }^{19}$ Sukma, masyarakat, wawancara (tanggal 11 Mei 2016)

${ }^{20}$ Mita, masyarakat, wawancara (tanggal 11 Mei 2016)

${ }^{21}$ Isma, masyarakat, wawancara (tanggal 11 Mei 2016)

${ }^{22}$ Risma, masyarakat, wawancara (tanggal 11 Mei 2016)
}

Journal Of Institution And Sharia Finance : Volume 3 Nomor 1 Juni 2020 
hal tersebut sebagai sesuatu yang wajar terjadi, tetapi ternyata masih ada sebagian kecil masyarakat yang merasa kurang puas dan tidak setuju jika praktek pembulatan harga dilakukan.

Dalam Islam ketidak puasan atau ketidak relaan tersebut dapat menandakan tidak adanya unsur 'antaradin pada salah satu pihak. Seperti yang diketahui bahwa dalam Islam bila ada perselisihan diantara dua orang yang berjual beli atau dengan kata lain tidak ada 'antaradin diantara mereka, maka dapat memilih mengikuti apa yang dikatakan penjual atau membatalkan jual beli tersebut. Bila dalam penggenapan uang sisa pembelian ini ada pembeli yang merasa kurang rela, ia dapat memilih untuk tetap mengikuti apa yang dikatakan penjual atau membatalkan jual beli tersebut.

Pandangan Islam tentang penggantian uang sisa pembelian dengan permen di minimarket Indomaret

Minimarket Indomaret merupakan salah satu tempat yang nyaman dalam berbelanja. Selain lebih praktis, fasilitas yang tersedia pun lebih lengkap da modern. Tak salah bila banyak masyarakat yang lebih memilih untuk berbelanja di Indomaret daripada pasar tradisioal.Di pasar tradisional mulai buka pada waktu pagi sampai sore saja, sedangkan Indomaret buka sampai malam.

Banyaknya konsumen yang berbelanja di Indomaret berarti banyak pula keuntungan yang diperoleh.Dilain pihak Indomaret juga harus mampu memberikan pelayanan yang memuaskan kepada pelanggannya.Ada beberapa jenis pelayanan kosumen yang harus dilakukan, salah satunya adalah pelayanan dalam transaksi pembayaran.

Saat ini peredaran uang receh telah berkurang sehingga sulit untuk didapatkan.Hal ini menjadi masalah yang dihadapi oleh pihak Indomaret.Demi pelayanan yang baik kepada konsumennya terutama dalam hal uang kembalian, pihak Indomaret tetap berusaha menyediakan uang receh yang digunakan dalam pengembalian uang sisa pembelian, meskipun dalam jumlah yang terbatas.

Semakin langka dan sulitnya mendapatkan uang pecahan kecil atau uang receh telah menimbulkan berbagai dampak bagi kegiatan perdagangan. Yang membuat pedagang mencari cara agar mereka bisa mengembalikan uang sisa pembelian milik konsumennya. Salah satu cara yang telah banyak dilakukan para pedagang saat ini adalah mengganti uang sisa pembelian dengan memberikan permen. Seperti yang dikatakan Maulid, kasir Indomaret bahwa : 
"Di Indomaret sudah disediakan uang receh tapi terkadang tidak cukup karena keterbatasan uang receh yang sedikit.Jika uang receh masih ada maka uang kembalian konsumen dikembalikan.Tetapi bila uang receh sudah habis maka uang kembalian dibulatkan dan diganti dengan permen. ${ }^{23}$ "

Bila dicermati lagi pengenapan uang sisa pengembalian dan pengantian uang sisa pengembalian dengan permen terdapat jual beli baru atau akad jual beli tambahan.Dengan menerima uang sisa pengembalian dalam bentuk permen berarti secara tidak langsung kita telah membeli permen tersebut.Hukum kedua akad tersebut adalah diperbolehkan dalam fiqih, kedua akad tersebut termasuk akad jual beli mu'athah yang telah diperbolehkan oleh jumhur ulama'.Hal ini memunculkan hukum satu kaidah yang berbunyi “adanya kesulitan memunculkan adanya kemudahan" hukum kaidah ini kemudian menimbulkan hukum rukhsah yang merupakan keringanan yang diberikan dalam keadaan-keadaan tertentu.

Dalam hal ini Imam Abu Hanifah, jumhur ulama' fiqh termasuk didalamnya ada ulama dari madzhab asy-Syafi'i dari generasi belakangan, yakni Imam Al-Nawawi, secara jelas dan tegas berpendapat bahwa jual beli mu'atah hukumnya adalah sah bila hal tersebut telah menjadi kebiasaan masyarakat dan hal tersebut tidak merugikan pihak lain. ${ }^{24}$ Kemampuan dan potensi yang dimiliki manusia dalam memikul hukum itu berbeda-beda, sehingga perlu diadakan jalan untuk menghindarai kesukaran dengan mengadakan pengecualian hukum.

Dilihat dari kaidah fikih maka boleh karena kondisi kelangkaan uang receh yang kemudian tidak mencukupi kebutuhan.Sebagaimana telah disebutkan, bahwa praktek pengenapan bisa terjadi dimana-mana dan sebagian besar masyarakat juga telah menganggap hal tersebut sebagai suatu yang wajar dan dapat dimaklumi.Tetapi dilain pihak, tidak dapat dipungkiri bahwa masih ada sebagian orang yang merasa kurang puas dengan adanya pengenapan ini.Ketidak puasan pembeli ini tidak bisa merusak sahnya akad, sebab pembeli dalam hal ini masih bisa khiyar.

Al-Khiyar (hak memilih) adalah mencari kebaikan dalam dua perkara, antara menerima atau membatalkan sebuah akad. ${ }^{25}$ Dalam jual beli menurut agama Islam dibolehkan memilih, apakah meneruskan jual beli atau membatalkannya karena sesuatu hal.Khiyar dibagi menjadi tiga macam, diantaranya yaitu:

\footnotetext{
${ }^{23}$ Maulid, kasir Indomaret, wawancara (pada tanggal 7 Agustus 2016)

${ }^{24}$ Al-Imam Kamaluddin Muhammad ibn Abd al-Wahid al-Siwasi ibn Humam, Syarh Fath al Qadir, (Beirut: Dar al-fikr, 1977), Juz VI, h. 252-253
}

${ }^{25}$ Sabiq, Fiqih Sunnah, Jilid 4, Bandung: Al-Ma'arif, h. 158

Journal Of Institution And Sharia Finance : Volume 3 Nomor 1 Juni 2020 
1. Khiyar majelis, artinya penjual dan pembeli boleh memilih, akan melanjutkan jual beli atau membatalkannya. Selama keduanya masih berada dalam suatu tempat (majelis). Khiyar majelis boleh dilakukan dalam berbagai jual beli.

2. Khiyar syarat, penjualan yang didalamnya disyaratkan sesuatu baik oleh penjual maupun pembeli, seperti seseorang berkata "saya jual rumah ini dengan harga Rp.100.000.000,- dengan syarat khiyar selama tiga hari."

3. Khiyar aib, artinya hak yang dimiliki seorang aqidain untuk membatalkan akad atau tetap melangsungkannya ketika menemukan cacat pada objek akad dimana pihak lain tidak memberitahukannya pada saat akad.

Dalam jual beli hendaknya berlaku jujur ini disyaratkan kesempurnaan benda-benda yang dibeli, diharamkan menjual barang cacat tanpa penjelasan kepada pembeli jika barang yang cacat masih dalam genggaman penjual, maka transaksi akan menjadi batal dengan penolakan pembeli.

\section{KESIMPULAN}

Berdasarkan dari hasil penelitian di atas yang sudah di gambarkan pada bab sebelumnya, maka pada bagian ini peneliti akan menyimpulkan beberapa hasil penelitian di atas sebagai berikut :

1. Dalam persepsi masyarakat terhadap pembulatan harga pada transaksi jual beli di minimarket Indomaret Kelurahan Pontap Kota Palopo memiliki arti yang sangat penting untuk diketahui. Adapun persepsi masyarakat dengan adanya praktek penggenapan uang sisa pengembalian sudah menjadi kebiasaan masyarakat tidak hanya di Indomaret tetapi juga terjadi di toko-toko, minimarket dan supermarket yang lain. Meskipun mayoritas masyarakat telah menganggap hal tersebut sebagai sesuatu yang wajar terjadi, tetapi ternyata masih ada sebagian kecil masyarakat yang merasa kurang puas dan tidak setuju jika praktek pembulatan harga dilakukan. Dalam Islam ketidak puasan atau ketidak relaan tersebut dapat menandakan tidak adanya unsur 'antaradin pada salah satu pihak. Seperti yang diketahui bahwa dalam Islam bila ada perselisihan diantara dua orang yang berjual beli atau dengan kata lain tidak ada 'antaradin diantara mereka, maka dapat memilih mengikuti apa yang dikatakan penjual atau membatalkan jual beli tersebut. Bila dalam penggenapan uang sisa pembelian ini ada pembeli yang merasa kurang rela, ia dapat memilih untuk tetap mengikuti apa yang dikatakan penjual atau membatalkan jual beli tersebut. 
2. Pandangan Islam tentang penggantian uang sisa pembelian dengan permen adalah diperbolehkan, melihat kelangkaan uang receh sehingga membuat pengelola Indomaret menyediakan permen sebagai gantinya. Hal ini memunculkan hukum satu kaidah yang berbunyi "al adanya kesulitan memunculkan adanya kemudahan". Kemampuan dan potensi yang dimiliki manusia dalam memikul hukum itu berbeda-beda, sehingga perlu diadakan jalan untuk menghindarai kesukaran dengan mengadakan pengecualian hukum. Imam Abu Hanifah, jumhur ulama' fiqh termasuk didalamnya ada ulama dari madzhab asy-Syafi'i dari generasi belakangan, yakni Imam Al-Nawawi, secara jelas dan tegas berpendapat bahwa jual beli mu'atah hukumnya adalah sah bila hal tersebut telah menjadi kebiasaan masyarakat dan hal tersebut tidak merugikan pihak lain.

\section{SARAN-SARAN}

Bekenaan dengan persepsi masyarakat terhadap pembulatan harga pada transaksi jual beli menurut syari'at Islam di minimarket Indomaret kelurahan Pontap kota Palopo, maka lewat kajian ini, di sarankan kepada pihak Indomaret dalam pemberian harga pada barang sebaiknya menggunakan harga bulat saja sehingga tidak perlu lagi adanya pembulatan harga pada saat poses pembayaran di kasir, dan tidak perlu menyediakan uang receh dan permen.

Kepada pihak pengelola minimarket Indomaret untuk tidak terjerumus dalam melakukan hal-hal yang bertentangan dengan aturan agama, di harapkan agar pihak pengelola Indomaret dan masyarakat yang menjadi pelanggan agar tetap konsisten dalam ajaran agama Islam agar tidak terjadi hal-hal yang bertentangan dengan syaiat Islam itu sendiri. Hendaknya pihak pengelola minimarket Indomaret dan pelanggan menanamkan dalam diri mereka sifat kejujuraan dan saling percaya, sehingga dapat diilai ibadah kepada Allah swt.

Diharapkan pihak pengelola minimarket Indomaret Kelurahan Pontap Kota Palopo agar kiranya menyadari pentingnya memahami dan mengetahui cara jual beli secara syariat Islam.

\section{DAFTAR PUSTAKA}

Abdul Hakim, Atang. Fiqih Perbankan Syari'ah, Bandung: Refika Aditama, 2011.

Abdurrahman, As-Sa'di, Syeikh, dkk. Fiqih Jual Beli, Jakarta: Kencana Prenada Media Group, 2010.

Afandi, Yazid. Fiqh Muamalah, Yogyakarta: Logung Pustaka, 2009. 
Arikunto, Suharsimi. Prosedur Penelitian Suatu Pendekatan Praktek, Ed.1. Cet.3; Jakarta: Rineka Cipta, 2002.

Al-Gazali, Imam. Benang Tipis Antara Halal dan Haram, Cet. I; Surabaya: Putra Pelajar, 2002

Athar, Sistem Transaksi Jual Beli di Supermarket PT Citra Sarana Sejahtera Opsal Plaza Menurut Syariat Islam, Skripsi. Palopo: Program Sarjana S1, 2013.

Abdul Hakim, Atang. Fiqih Perbankan Syari’ah, Bandung; Refika Aditama, 2011

Arsip, Sejarah Berdiri Indomaret

Arsip, Indomaret Kelurahan Pontap Kota Palopo

Bugi, Mochamad. Mochamad Bugi, Mengenal Syariat Islam,http:/ www.dakwatuna. com/2008,/2/412/mengenal-syariat-islam-bagian-1, di akses pada tanggal 27 November 2015

Departemen Agama RI, Al-Qur'an dan Terjemahnya, Edisi Revisi; Bandung: Deponegoro, 2011.

Departemen Pendidikan Nasional, Kamus Besar Bahasa Indonesia, Ed.3; Cet.4; Jakarta: Balai Pustaka, 2007

Djuwaini, Dimyauddin. Pengantar Fiqih Muamalah, Yogyakarta: Pustaka Pelajar, 2008.

Fakhurrozi. At Tafsir Al Kabir, Cet; II: Teheran: Dar Al Kutub Al Ilmiyah

Haroen, Nasrun. Fiqhi Muamalah, Jakarta: Gaya Media Pratama, 2000

Imam Abu Husain bin Hajjaj Al Qusyari Annaisaburi, Muslim. Kitab Muslim Jus 2, Lebanon: Darul Fikr-Bairut, 1993.

Issa Beekun, Rafik. Etika Bisnis Islam, Cet. I; Yogyakarta: Pustaka Pelajar, 2004

Ilyas, Pelaksanaan Sistem Jual Beli di Toko Pembangunan Kota Palopo dalam Persfektif Syariat Islam, Skripsi. Palopo: Program Sarjana (S1), 2011

Kamaluddin Muhammad ibn Abd al-Wahid al-Siwasi ibn Humam, al-Imam. Syarh Fath al Qadir, Beirut: Dar al-fikr, 1977, Juz VI

Lubis, Suhrawardi K. Hukum Ekonomi Islam, Cet.II; Jakarta: Sinar Grafindo, 2000.

Muhammad Al-Jamal, Ibrahim. Fiqih Muslimah Ibadat Mu'amalat, Cet. III; Jakarta: Pustaka Amani, 1999. 
Margono, S. Metode Penelitian Pendidikan, Cet. IV; Jakarta: Asdi Mahasatya, 2004.

Mas'ud, Ibnu dan Zainal Abidin. Fiqih Mazhab Syafi'I, Cet. I; Bandung: Pustaka Setia, 2000.

Mutahari, Murtadha. Man and Universe, diterjemahkan oleh ; Ilyas Hasan dengan judul : Manusia dan Alam Semesta, Cet; I; Jakarta; Lentera Basritama, 2002.

Najatullah, Muhammad. Kegiatan Ekonomi dalam Islam, Cet.II; Jakarta: Bumi Aksara, 1996.

Narbuko, dan Abu Ahmadi, Cholid. Metodologi Penelitian, Cet. 12; Jakarta: Bumi Aksara, 2012.

Nur Ichwan Muslim, Muhammad. Artikel www.muslim.co.id, 25 November 2015

Official, Indomaret. Indomaret menyerahkan donasi kosumen ke UNICEF, dalam http://www.indomaret.co.id

Pendidikan Nasional, Departemen. Kamus Besar Bahasa Indonesia, Ed.3; Cet.4; Jakarta: Balai Pustaka, 2007

Rahman Ghazali, Abdul. Fiqh Muamalat, Jakarta: Kencana Prenada Media Group, 2010.

Ruslan, Rosady. Metode Penelitian Public Relations da Komunikasi, Ed.1, Cet.3; Jakarta: Raja Grafindo Persada, 2006.

Sabri, Alisuf. Pengantar Psikologi Umum dan Perkembangan, Cet.IV; Jakarta: Pedoman Ilmu Jaya, 2006

Suhendi, Hendi. Fiqih Muamalah, Jakarta: Raja Grafindo Persada, 2002.

Sukma, masyarakat kelurahan Pontap, wawancara, tanggal 11 Mei 2016.

Syafei, Rahmat. Fiqih Muamalah, Cet.I; Bandung: Pustaka Setia.

Thabari, Ath. Jami' Al Bayan, Cet; II: Kairo: Dar Al Ma'arif, 1954.

Umar, Nasruddin. Argumen Kesetaraan Jender, Cet. I; Jakarta: Paramadina, 1999.

Wiroso, Jual Beli Murabahah, Yogyakarta: Logung Pustaka, 2009.

Yusuf Musa, Muh. Al Fiqh Al Islam, Kairo: Dar Al Kutub Al Haditsah, 1954. 